\title{
Ecology of small neritic fishes in the western Gulf of Alaska. I. Geographic distribution in relation to prey density and the physical environment
}

\author{
Matthew T. Wilson* \\ Alaska Fisheries Science Center, National Marine Fisheries Service, National Oceanic and Atmospheric Administration, \\ 7600 Sand Point Way NE, Seattle, Washington 98115, USA
}

\begin{abstract}
Physical heterogeneity affects the geographic structure of coastal ocean ecosystems by influencing the spatial distribution of zooplankton and their nektonic predators. This was examined in the western Gulf of Alaska (GOA) during late summer (2000, 2001, and 2003) when seasonal increases in the Alaska Coastal Current flow and additions of Age-0 fishes to the nektonic community of small neritic fishes coincided with declining zooplankton abundance. The 48-site sampling grid was divided into 5 meso-scale areas based on physical condition (temperature, salinity, net current velocity). Larval crabs and fishes, and krill were the only zooplankton taxa for which the population density consistently differed by area regardless of diel period (day, night) or year. Larval crabs and fishes concentrated near shore in warm, low-salinity water. Krill concentrated in high-flow areas, which, over the shelf, were associated with sea valleys. Dominant fishes were walleye pollock Theragra chalcogramma, capelin Mallotus villosus, and eulachon Thaleichthys pacificus. Few fish occurred beyond the shelf in the cold, swift-flowing Alaskan Stream boundary current. Over the shelf, Age-1+ walleye pollock and eulachon aggregated with krill in high-flow areas. Smaller fishes (Age-0 walleye pollock and capelin) were more variably distributed, and were not well associated with taxon-specific zooplankton densities. Thus, relatively high flow in proximity to sea valleys was associated with concentrations of krill and fishes that presumably were able to efficiently forage on krill in high-flow areas. The year-to-year consistency in patterns is a noteworthy indication that geographic structure in the coastal GOA ecosystem may resist climate forcing.
\end{abstract}

KEY WORDS: Walleye pollock $\cdot$ Capelin $\cdot$ Eulachon $\cdot$ Zooplankton $\cdot$ Population density $\cdot$ Body size

\section{INTRODUCTION}

Interaction between ocean currents and topography affects the spatial ecology of small neritic fishes within the nektonic community. Best known, perhaps, are the large-scale concentrations of small fishes in upwelling regions of eastern boundary currents (Fréon et al. 2005, Mann \& Lazier 2006). Elsewhere, large influxes of Atlantic water into the Barents Sea from the west cause northeastward shifts in the basin-wide spatial distribution of capelin Mallotus villosus (Gjøsæter 1998). These influxes also affect large-scale spatial distributions of juvenile cod Gadus morhua and their zoo- plankton prey (Helle \& Pennington 1999). Off Japan, the Tsugaru Warm Current seasonally influences circulation within Hidaka Bay, apparently generating an exceptional (southeasterly) coastal current that affects the distribution of juvenile walleye pollock along the coast from natal to nursery areas (Honda et al. 2004). At smaller scales, currents impinging on abrupt topographies create flow fields that, in combination with animal behavior (e.g. directed swimming), can lead to local accumulation of zooplankton and zooplanktivores resulting in 'trophic focusing' (Genin 2004). In the Gulf of Alaska (GOA), Cooney (1986) hypothesized that physical processes contribute to 
ecosystem productivity by facilitating local accumulations of zooplankton and zooplanktivores. This hypothesis has not been well tested, but is relevant to understanding the climate forcing of the GOA ecosystem.

In the GOA, the oceanography in Shelikof Strait and southwestward to the Shumagin Islands is well known from process-oriented studies of walleye pollock Theragra chalcogramma recruitment (Kendall et al. 1996). Circulation is dominated by the Alaska Coastal Current (ACC), which is structured by freshwater input and driven along the coast by wind (Stabeno et al. 2004). The ACC exits Shelikof Strait and flows around Semidi Bank (Fig. 1) (Schumacher \& Reed 1986). Some flow continues over the northern part of Semidi Bank and along the Alaska Peninsula, but net current velocity is reduced (4 to $16 \mathrm{~cm}$ $\mathrm{s}^{-1}$ ). Most flow, however, is diverted southward at 20 to $30 \mathrm{~cm} \mathrm{~s}^{-1}$ over the Shelikof sea valley and along the eastern flank of Semidi Bank toward the slope. Offshore flow in the upper water column drives the estuarine circulation within Shelikof, drawing water at depth into the sea valley from the slope. Over the slope, the ACC water may join the Alaskan Stream, a southwestward current with peak speeds of $100 \mathrm{~cm} \mathrm{~s}^{-1}$ along the shelf-slope boundary (Reed \& Schumacher 1986). Some ACC water may re-enter the shelf in the Shumagin sea valley.

Small neritic fishes are abundant members of the nekton in the Shelikof-Shumagin area. The abundance of young-of-the-year (Age-0) walleye pollock during late summer (Brodeur \& Wilson 1996) is at least partly explained by downstream movement of fish spawned in Shelikof Strait (Hinckley et al. 1991). The juveniles feed primarily on krill (Euphausiacea) and copepods (Brodeur \& Wilson 1996). Other prominent neritic fishes include capelin and eulachon Thaleichthys pacificus. These fishes are valued as abundant, energyrich prey species (Iverson et al. 2002). Capelin consume krill and copepods and may compete with Age-0 walleye pollock (Wilson et al. 2006). Much less is known about the marine habits of eulachon, which are anadromous (Willson et al. 2006).

The present study was conducted by the Ecosystems and Fisheries-Oceanography Coordinated Investigations (EcoFOCI) Program to examine possible responses of small neritic fishes within the nekton community to concentrations of zooplankton associated with physical environment heterogeneity. Response

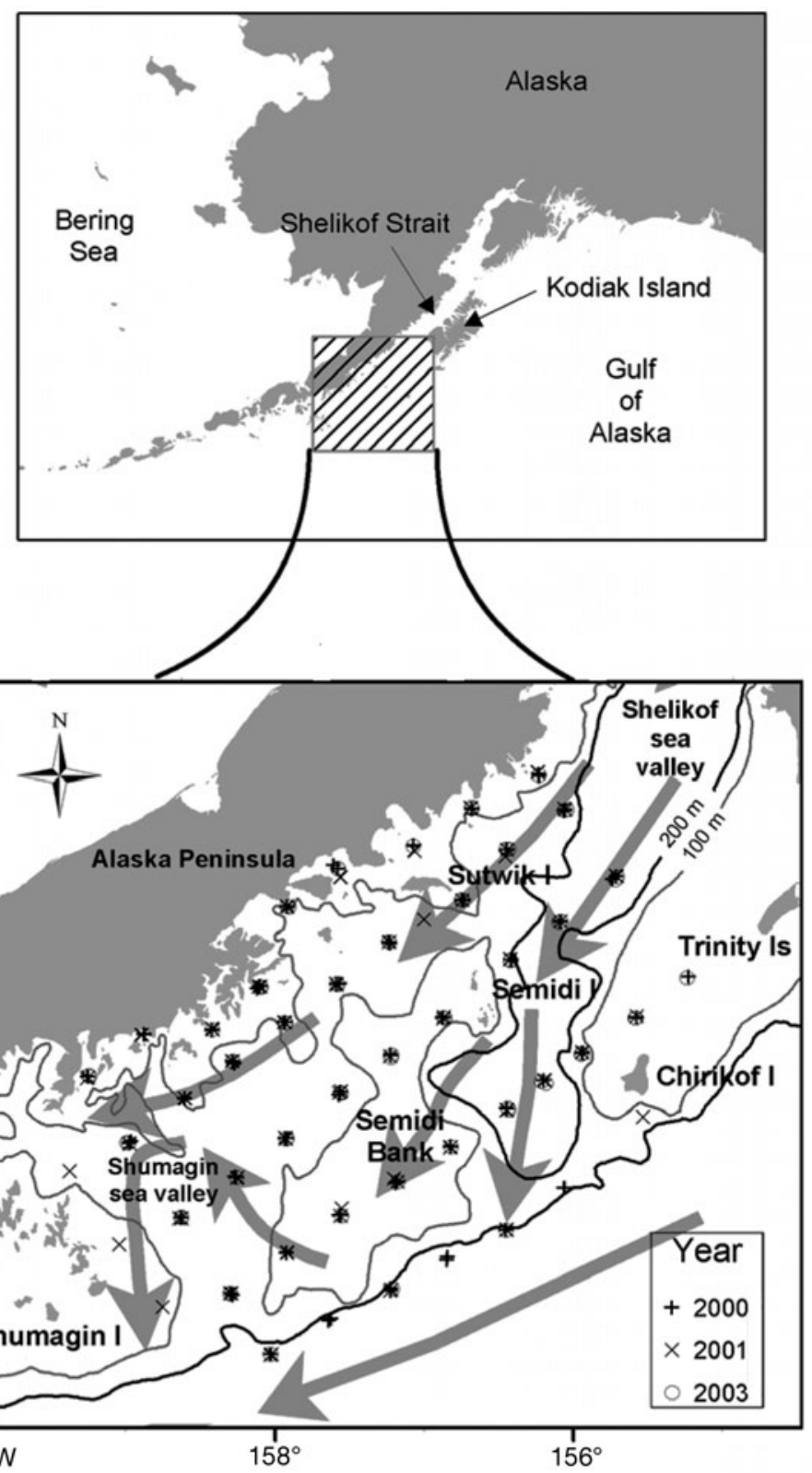

Fig. 1. Sampling locations in the western Gulf of Alaska that were occupied during September 2000, 2001, and 2003 to collect neritic fishes and zooplankton. Net current flow is indicated in the bottom panel by gray arrows (adapted from Reed \& Schumacher 1986)

variables considered in the current paper are fish population density and body length. Fish diet analyses are presented separately (Wilson et al. 2009, this volume). Sampling occurred in late summer (September 2000, 2001, 2003), when increased ACC flow (Stabeno et al. 2004) and influx of Age-0 fish (e.g. Brodeur \& Wilson 1996) coincide with declining zooplankton abundance (Coyle \& Pinchuk 2003), perhaps intensifying the hypothesized geographic associations. The focus was on consistent year-to-year meso-scale geographic vari- 
ation to lay the foundation for future investigation of mechanistic processes (e.g. localized upwelling) and temporal variability (e.g. year to year) as needed to understand ecosystem forcing mechanisms. Specific objectives were to (1) test for differences in zooplankton population density and fish population density and body length among areas of different physical condition to elucidate taxa whose geographic distribution persists year to year, (2) identify which fish (i.e. predator) taxa correlate geographically with which zooplankton (i.e. prey) taxa in terms of population density and (3) examine the geographic distributions of correlated taxa in relation to the physical environment to identify possible causal mechanisms.

\section{MATERIALS AND METHODS}

The study area was between Shelikof sea valley and the Shumagin Islands from near shore to the continental slope (Fig. 1). A 48-site sampling grid was constructed, with sites allocated to avoid navigational hazards and to represent major bathymetric regions $(<100$, 100 to 200 , and $>200 \mathrm{~m}$ water depth). Most sites were sampled once by day and again at night, usually within $24 \mathrm{~h}$. No samples were collected during twilight. The NOAA ship 'Miller Freeman' was used to sample the upper $200 \mathrm{~m}$ of water.

Physical environment. Water temperature, salinity, and model-based estimates of net current velocity were used to characterize site physical environment. Temperature and salinity profiles were measured with a calibrated Sea-Bird Electronics ${ }^{1}$ (SBE) 19 SeaCat profiler fished with the plankton net. Profiler accuracy was confirmed with a calibrated SBE 911 Plus CTD. Net current velocity at $40 \mathrm{~m}$ depth was estimated from the rigid-lid, semi-spectral, primitive equation model (SPEM) (Hermann \& Stabeno 1996). Model output represents the major circulation features within the Shelikof sea valley (Stabeno \& Hermann 1996) and within a larger area (Schumacher \& Reed 1986), which approximates the present study area. Daily current vectors were generated at $4 \mathrm{~km}$ intervals for September and converted to polar coordinates. Velocity was averaged by spatial cell and year to estimate mean daily net current velocity. The SPEM domain did not extend into near-shore areas. Mean velocities were contoured using the inverse distance-weighted interpolation scheme in ArcMap (Ver. 8.2) (ESRI). Geographic distributions of temperature, salinity, and net current velocity were then used to visually divide the study area into 5 subareas, hereafter referred to as 'hydrographic' areas.

${ }^{1}$ Use of trade names does not imply endorsement by the National Oceanic and Atmospheric Administration.
Zooplankton. A $1 \mathrm{~m}^{2}$ Tucker trawl (0.333 mm mesh) equipped with calibrated General Oceanics flowmeters was used to collect zooplankton. The trawl was fished obliquely from $200 \mathrm{~m}$ depth or, if shallower, $10 \mathrm{~m}$ off the bottom, to the surface. The SeaCat profiler provided real-time net depth. Samples were preserved in $5 \%$ formalin and sorted at the Polish Plankton Sorting and Identification Center (Szczecin, Poland). Following Siefert \& Incze (1991), samples were sorted after removing debris and large organisms (e.g. shrimp and scyphozoans) and enumerating the individuals by taxonomic category. Large samples were subsampled using a Folsom plankton splitter.

Depth-integrated catch data were grouped into 15 broad taxonomic groups following Wilson et al. (1996). Copepods were divided into small $(<2 \mathrm{~mm}$ prosome length [PL]) and large copepods ( $\geq 2 \mathrm{~mm} \mathrm{PL}$ ). Euphausiid furciliae were distinguished from juvenile and adult euphausiids; hereafter, 'krill' refers only to juvenile and adult euphausiids. Population density (ind. $\mathrm{m}^{-3}$ ) was total catch standardized to $1 \mathrm{~m}^{3}$ of water filtered.

Fishes. Fishes were collected using a Stauffer (also known as an anchovy trawl) midwater trawl (WyllieEcheverria et al. 1990), equipped with a $3 \mathrm{~mm}$ mesh codend liner. The trawl was fished with $1.5 \times 2.1 \mathrm{~m}$ steel-V otter doors (566 kg each). It was deployed at $50 \mathrm{~m} \mathrm{~min}^{-1}$, allowed to settle at $20 \mathrm{~m}$ (headrope depth) above the bottom, and then retrieved at $10 \mathrm{~m} \mathrm{~min}^{-1}$. Net depth was monitored with a Furuno net sounder. Ship speed over ground was 2.5 to 3.0 knots.

The catch was sorted, enumerated, and weighed at sea. Following Brodeur \& Wilson (1996), Age-0 walleye pollock were distinguished from older age groups (Age-1+) by a distinct difference in body length. Age-0 walleye pollock Theragra chalcogramma, capelin Mallotus villosus, and eulachon Thaleichthys pacificus were measured to the nearest $1 \mathrm{~mm}$ standard length (SL). Age-1+ walleye pollock were measured to the nearest $1 \mathrm{~cm}$ fork length, which was converted to SL following Buchheister \& Wilson (2005). No more than 100 fish per group were measured per tow.

Catch numbers and weights were standardized by volume filtered (ind. $\mathrm{m}^{-3}$ ). Volume filtered was estimated from mean trawl mouth area and ship travel distance between trawl door deployment and recovery. For each tow, elliptical mouth area $\left(\mathrm{m}^{2}\right)$ was predicted at $1 \mathrm{~m}$ intervals of wire out from surface to maximum wire out $\left(R^{2}=0.98, N=697\right)$, such that:

$$
\text { Mouth area }=95.183\left\{1-\mathrm{e}^{[-0.011(x+83.207)]}\right\}
$$

where $x$ is wire out. Net-mouth dimension (vertical and horizontal opening) data were collected using a Scanmar $\underline{1}$ net mensuration system. 
Data analysis. Analysis of variance (ANOVA) tests were used to examine hydrographic area, diel, and year effects on zooplankton and fish geographic distributions. The dependent variables were population density of zooplankton and fish, and fish length. A separate test was conducted for each taxon. The ANOVA model was:

$$
\begin{aligned}
Y_{\text {ikady }}= & \alpha+\operatorname{area}_{a}+\operatorname{diel}_{d}+\text { year }_{y} \\
& +\operatorname{area}_{a} \times \operatorname{diel}_{d}+\operatorname{area}_{a} \times \text { year }_{y} \\
& +\operatorname{diel}_{d} \times \text { year }_{y} \\
& +\operatorname{area}_{a} \times \operatorname{diel}_{d} \times \text { year }_{y}+\operatorname{site}_{k}\left(\operatorname{area}_{a}\right)+e_{i k a d y}
\end{aligned}
$$

where $Y_{i k a d y}$ is the dependent variable (i.e. zooplankton density, fish density, or fish length) from the $i$ th sample collected at the $k$ th collection site in the ath hydrographic area during the $d$ th diel period in the $y$ th year and $e_{i k a d y}$ is the random error. Area, diel, and year were fixed effects. Site was nested within area, and the nested term was included as a random effect. Following Milliken \& Johnson (1996), the model was reduced by sequentially dropping nonsignificant $(p>0.05)$ terms beginning with the 3-way interaction, then 2-way interactions, and finally any main effects not included in any retained interaction term(s). Zooplankton and fish population densities were fourth-root transformed to make the residual error structure normal. One statistical cell was empty due to no zooplankton sampling at slope stations during night 2003. The cell was filled using day/night ratio estimators (Cochran 1977; $\mathrm{N}=111$ pairs) applied to density estimates from 3 slope sites occupied during the day in 2003. Fish length was averaged by sample and weighted by population density. Few fish were collected over the slope so it was not included as an area-effect level in the tests of fish length. For Age-0 walleye pollock, mean length was adjusted to the overall median survey date (12 September) using a growth rate of $0.89 \mathrm{~mm}$ $\mathrm{d}^{-1}$ (Bailey et al. 1996); this adjustment did not substantially alter test conclusions. Two infrequently occupied sites near Chirikof Island were omitted from the analysis; these were shallower than adjacent sites and outside the SPEM domain. Tests were conducted using the SAS System for Windows (Release 8.02).

\section{RESULTS}

Overall, 230 plankton tows and 235 trawl hauls were successfully conducted (Table 1). There was insufficient time to sample all sites each year. Fewer samples were collected at night compared to during the day, due to the relatively short nights.
Table 1. Fish (midwater trawl hauls) and plankton (net tows) samples tallied by year and diel period. All samples were collected at pre-determined stations in the western Gulf of Alaska during September

\begin{tabular}{|cccc|}
\hline Year & Diel period & $\begin{array}{c}\text { Midwater trawl } \\
\text { hauls }\end{array}$ & $\begin{array}{c}\text { Plankton } \\
\text { net tows }\end{array}$ \\
\hline 2000 & Night & 43 & 43 \\
& Day & 42 & 43 \\
2001 & Night & 39 & 39 \\
& Day & 43 & 43 \\
2003 & Night & 31 & 28 \\
& Day & 37 & 34 \\
Total & & 235 & 230 \\
\hline
\end{tabular}

\section{Physical environment}

Across-shelf gradients in salinity and temperature were consistent from year to year (Fig. 2). Salinity at $40 \mathrm{~m}$ depth ranged from 29.9 to $32.7 \mathrm{psu}$. Mean salinity decreased from 2000 (31.9 psu) to 2001 (31.7 psu) to 2003 (31.4 psu), driven primarily by decreases in nearshore salinity, an ACC indicator (Schumacher \& Reed 1986). Salinity profiles from the Shumagin sea valley revealed an increase in near-bottom salinity indicative of oceanic influx at depth as noted by Schumacher \& Reed (1986).

Water temperature at $40 \mathrm{~m}$ depth ranged from 6.5 to $12.2^{\circ} \mathrm{C}$. Mean temperature increased from $2000\left(8.6^{\circ} \mathrm{C}\right)$ to $2001\left(9.6^{\circ} \mathrm{C}\right)$ to $2003\left(10.3^{\circ} \mathrm{C}\right)$. Near-shore water was relatively warm. Based on the relatively fresh, warm water over the inner shelf, the study area was divided into inner- and outer-shelf areas (Fig. 2).

Geographic variability in net current velocity was consistent from year to year (Fig. 2). Over the shelf, velocities were usually $\leq 10 \mathrm{~cm} \mathrm{~s}^{-1}$, averaging $5.0 \mathrm{~cm} \mathrm{~s}^{-1}$ in 2000 , $9.3 \mathrm{~cm} \mathrm{~s}^{-1}$ in 2001, and $6.2 \mathrm{~cm} \mathrm{~s}^{-1}$ in 2003 , with relatively high values northeast in proximity to the Shelikof sea valley. Higher velocities over the slope were ascribed to the Alaskan Stream. Overall, the predominant direction of flow was southwestward. Based on the relatively high velocities over the slope and intermediate velocities northeast, the study area was divided into southwestshelf, northeast-shelf, and slope sub-areas. Superimposing the thermo-salinity and velocity-based subdivisions gave 5 hydrographic areas used to characterize interannually persistent, meso-scale geographic variation in the physical environment. Hereafter, each area is referred to by its relative geographic position: NEin, NEmid, SWin, SWmid, and Slope (see Fig. 4).

\section{Zooplankton}

Overall, 12 groups of holoplankton and 3 groups of meroplankton were collected in 230 samples (Table 2). 
Wilson: Ecology of neritic fish distributions

227
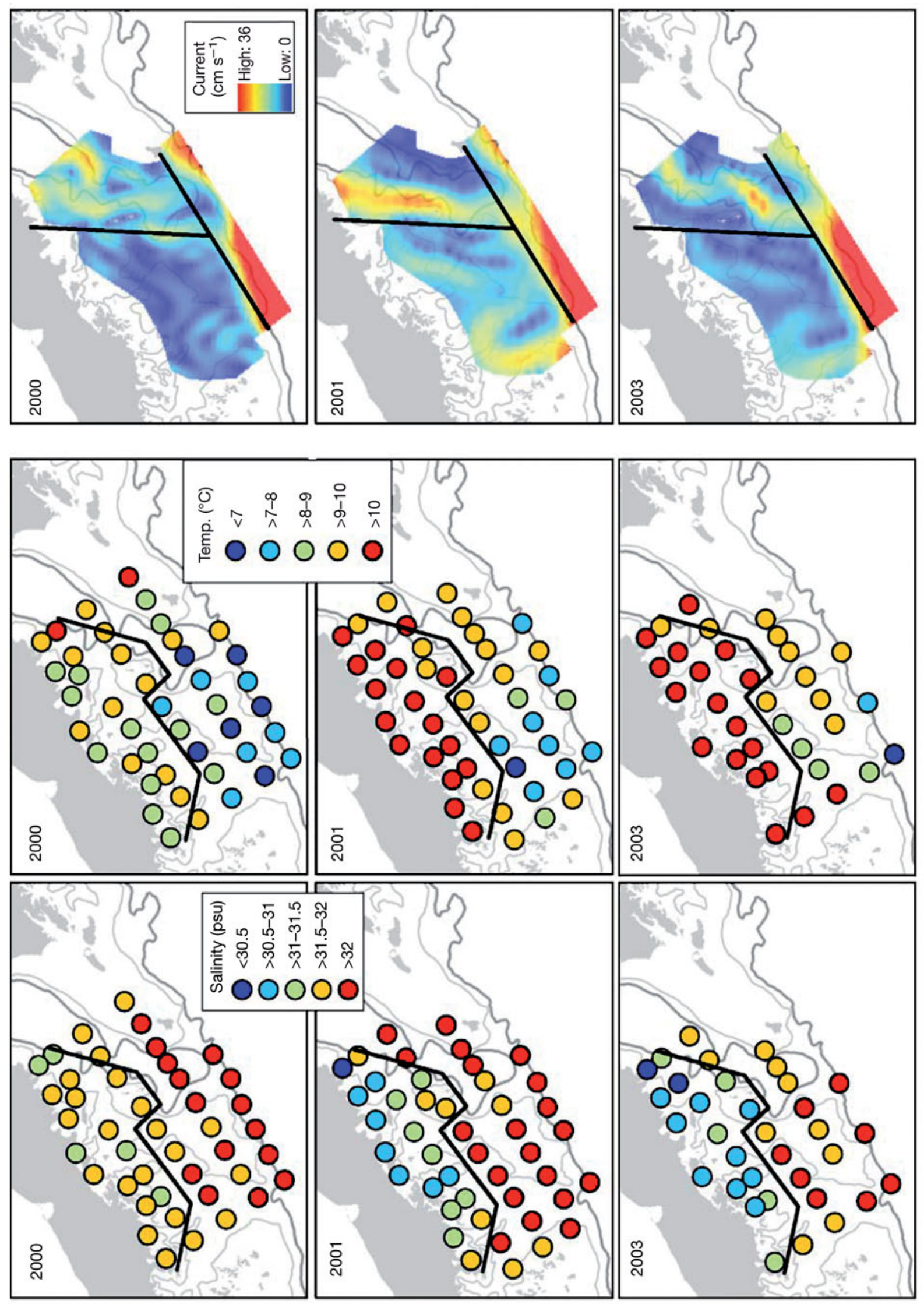

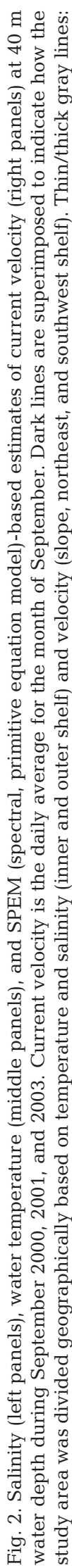


Table 2. Taxonomic composition of zooplankton collected with a $1 \mathrm{~m}^{2}$ Tucker trawl (333 $\mu \mathrm{m}$ mesh) from the upper $200 \mathrm{~m}$ depth in the western Gulf of Alaska during September 2000, 2001, and 2003. CI to CVI: copepodite Stages 1 to 6. Abbreviations of taxonomic groups are used in Table 3. Frequency of occurrence is the number of samples in which the taxonomic group occurred as a percentage of the total number of samples collected $(\mathrm{N}=230)$

\begin{tabular}{|c|c|c|}
\hline Taxonomic group (abbreviation) & $\begin{array}{c}\text { Frequency occurrence } \\
(\%)\end{array}$ & $\begin{array}{l}\text { Density } \\
\text { (ind. } \mathrm{m}^{-3} \text { ) }\end{array}$ \\
\hline Copepoda, small $(\mathrm{CopS})^{\mathrm{a}}$ & 100.0 & 569.838 \\
\hline Pseudocalanus spp., CI-CVI & 100.0 & 237.148 \\
\hline Acartia spp., CVI & 100.0 & 214.171 \\
\hline Unidentified Copepoda $<2 \mathrm{~mm}$ & 100.0 & 59.616 \\
\hline Oithona spp., CV-CVI & 98.6 & 20.340 \\
\hline Metridia pacifica, CIV & 97.7 & 24.413 \\
\hline Calanus spp. & 97.7 & 3.312 \\
\hline Metriididae, CI-CIII & 95.9 & 9.325 \\
\hline Eucalanus bungii, CI & 31.7 & 0.555 \\
\hline Neocalanus cristatus, CII & 19.5 & 0.053 \\
\hline Metridia spp., CIV & 9.0 & 0.887 \\
\hline Neocalanus spp., CII & 6.8 & 0.019 \\
\hline Copepoda, large (CopL) & 100.0 & 78.855 \\
\hline Metridia pacifica/lucens, CV-CVI & 100.0 & 40.163 \\
\hline Calanus marshallae, CIII-CVI & 100.0 & 30.062 \\
\hline Eucalanus bungii, CIII-CVI & 98.7 & 3.726 \\
\hline Calanus pacificus, CIV-CVI & 93.0 & 1.994 \\
\hline Unid./other Copepoda $\geq 2 \mathrm{~mm}$ & 73.9 & 0.930 \\
\hline Neocalanus cristatus, CIII-CVI & 64.3 & 0.283 \\
\hline Neocalanus spp., CIII-CVI & 50.9 & 0.335 \\
\hline Metridia spp., CV-CVI & 30.9 & 1.362 \\
\hline Chaetognatha (Chae) & 100.0 & 3.964 \\
\hline Cnidaria & 99.6 & 1.415 \\
\hline Euphausiid furciliae (EuFu) & 99.1 & 3.352 \\
\hline Osteichthys larvae (Oste) & 98.3 & 0.153 \\
\hline Thecosomata (Thec) ${ }^{\mathrm{a}}$ & 95.9 & 24.239 \\
\hline Euphausiacea, juvenile \& adult (Krill) & 84.3 & 2.086 \\
\hline Thysaneossa inermis & 70.4 & 1.082 \\
\hline Thysanoessa spinifera & 66.5 & 0.576 \\
\hline Unid./other euphausiids & 50.4 & 0.211 \\
\hline Euphausia pacifica & 38.3 & 0.116 \\
\hline Thysanoessa raschii & 31.3 & 0.085 \\
\hline Thysanoessa inspinata & 4.8 & 0.012 \\
\hline Thysanoessa longipes & 3.0 & 0.002 \\
\hline Tessarabrachion oculatum & 2.6 & 0.003 \\
\hline Natantia (Nata) & 77.4 & 0.794 \\
\hline Reptantia (Rept) & 76.1 & 2.036 \\
\hline Larvacea (Larv) ${ }^{\mathrm{a}}$ & 70.1 & 5.890 \\
\hline Siphonophora & 68.7 & 0.343 \\
\hline Amphipoda (Amph) & 33.5 & 0.085 \\
\hline Mysidacea (Mysi) & 16.5 & 0.017 \\
\hline Ctenophora & 7.8 & 0.009 \\
\hline All groups combined & 100.0 & 693.075 \\
\hline
\end{tabular}

Only crab larvae, fish larvae, and krill population densities varied consistently among geographic areas. The 5level, hydrographic area effect was significant $(p<0.05)$ for each group, and interaction with other effects was not significant ( $p>0.05)$ (Table 3$)$. The significant diel effect on fish larvae and krill population density was due to higher nighttime catches.

Population densities of crab larvae and fish larvae were highest in the relatively fresh, warm near-shore areas (Fig. 3). Larval crab populations were densest in the relatively low-flow SWin area, whereas larval fishes were densest in both low-flow and high-flow (NEin) areas. For larval crabs, the significant year effect was due to high population densities during the lowflow year 2000 and was low during the high-flow year 2001.

Population density of krill was highest in the NEmid area and lowest in the SWin (Fig. 3). Mean density within the SWmid area was intermediate, but the relatively high densities encountered near the $100 \mathrm{~m}$ isobath along the eastern edge of the Shumagin sea valley were indicative of finer scale geographic variability (Fig. 4). The significant year effect was due to high krill densities during the high-flow year 2001. Most krill identified to species (i.e. excluding unidentified individuals) in each area during 2001 were Thysanoessa inermis, whereas $T$. spinifera were proportionally more common in other years.

\section{Fishes}

Overall, 25 families of fishes were identified in 235 trawl catches (Table 4). The most frequently occurring nektonic Holoplanktonic crustaceans dominated the collection due to the prevalence of copepods and euphausiids. Meroplankton was represented by larval fishes, shrimps, and crabs. Three gelatinous-zooplankton taxa (cnidaria, ctenophora, siphonophora) were not considered further due to insufficient evidence of dietary importance to pollock Theragra chalcogramma, capelin Mallotus villosus, and eulachon Thaleichthys pacificus. species were walleye pollock, capelin, and eulachon. Combined, these 3 species made up $93 \%$ by abundance (ind. $\mathrm{m}^{-3}$ sample $^{-1}$ ) and $76 \%$ by weight $\left(\mathrm{mg} \mathrm{m}^{-3}\right.$ sample $^{-1}$ ) of all nektonic fishes collected (excluding the many small, presumably larval stichaeids and teleosts). These 3 species were encountered mostly in samples collected over the shelf as opposed to over the slope; consequently, subsequent results pertain to their distribution over the shelf. 
Table 3. Significance (p-values) of terms retained in reduced models from analysis of variance of year, diel, and area effects on the population density (ind. $\mathrm{m}^{-3}$ ) of each of 12 zooplankton groups (see Table 2 for definition of taxonomic group abbreviations). One test was conducted for each zooplankton group. Dashes indicate non-significant $(p>0.05)$ terms eliminated during model reduction

\begin{tabular}{|c|c|c|c|c|c|c|c|c|c|c|c|c|}
\hline \multirow{2}{*}{$\begin{array}{l}\text { Reduced model } \\
\text { terms }\end{array}$} & \multirow[b]{2}{*}{ CopS } & \multirow[b]{2}{*}{ CopL } & \multirow[b]{2}{*}{ Chae } & \multirow[b]{2}{*}{ EuFu } & \multirow[b]{2}{*}{ Oste } & \multirow{2}{*}{\multicolumn{2}{|c|}{$\begin{array}{l}\text { Taxonomic group } \\
\text { Thec Krill }\end{array}$}} & \multirow[b]{2}{*}{ Nata } & \multirow[b]{2}{*}{ Rept } & \multirow[b]{2}{*}{ Larv } & \multirow[b]{2}{*}{ Amph } & \multirow[b]{2}{*}{ Mysi } \\
\hline & & & & & & & & & & & & \\
\hline Year & 0.046 & 0.005 & 0.0035 & $<0.001$ & 0.027 & $<0.001$ & $<0.001$ & 0.495 & $<0.001$ & $<0.001$ & 0.097 & 0.029 \\
\hline Diel & - & 0.001 & - & - & $<0.001$ & - & $<0.001$ & - & - & - & $<0.001$ & $<0.001$ \\
\hline Area & $<0.001$ & 0.012 & $<0.001$ & $<0.001$ & $<0.001$ & $<0.001$ & 0.013 & $<0.001$ & $<0.001$ & 0.016 & $<0.001$ & 0.314 \\
\hline Year-Diel & - & - & - & - & - & - & - & - & - & - & $<0.001$ & - \\
\hline Year-Area & $<0.001$ & 0.01 & $<0.001$ & 0.031 & - & $<0.001$ & - & 0.001 & - & $<0.001$ & $<0.001$ & 0.042 \\
\hline Diel-Area & - & - & - & - & - & - & - & - & - & - & $<0.001$ & - \\
\hline Year-Diel-Area & - & - & - & - & - & - & - & - & - & - & $<0.001$ & - \\
\hline
\end{tabular}
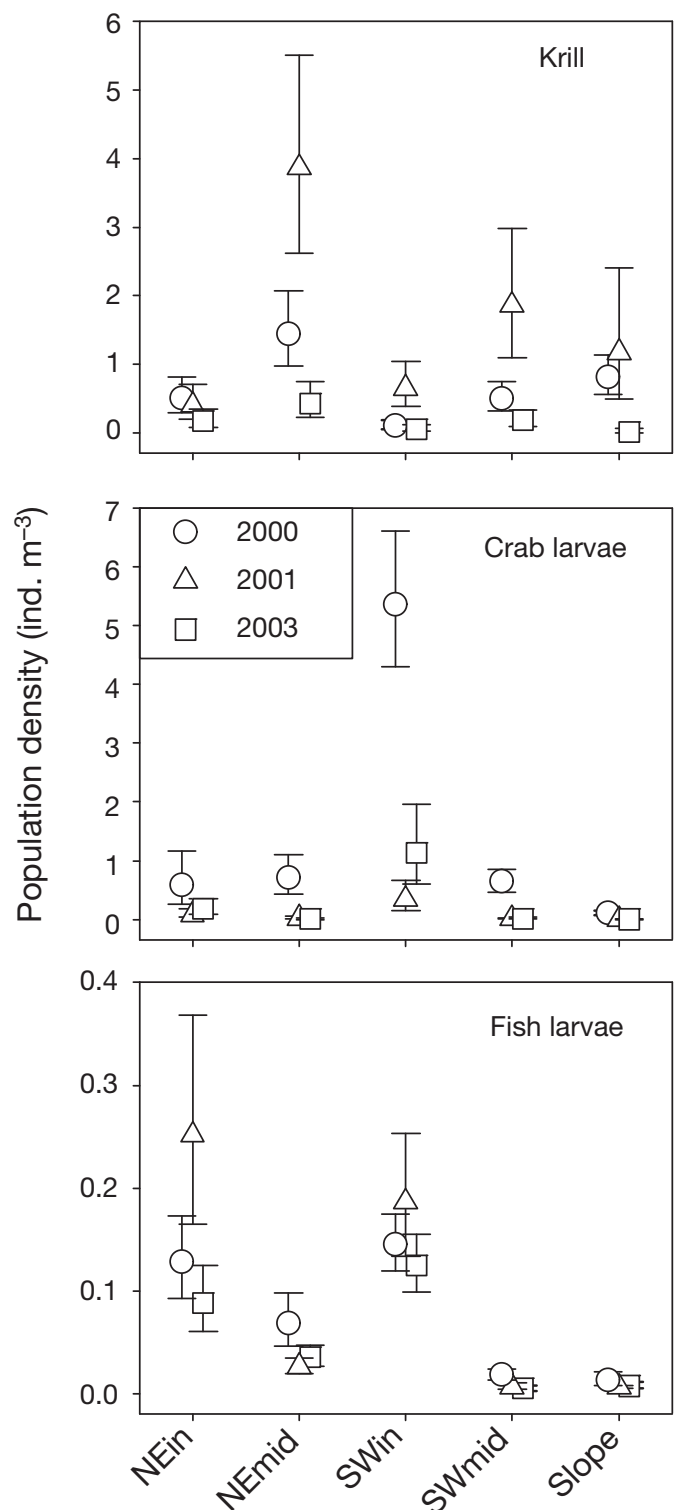

Fig. 3. Back-transformed mean $( \pm 1 \mathrm{SE})$ population density (ind. $\mathrm{m}^{-3}$ ) of krill, crab larvae, and fish larvae collected during day and night in 5 geographic areas (see Fig. 4) in the western Gulf of Alaska during September 2000, 2001, and 2003
Walleye pollock

Walleye pollock ranged in length from 38 to $677 \mathrm{~mm}$ SL, with a multimodal size frequency distribution (Fig. 5). The distinct break in size at 120 to $130 \mathrm{~mm} \mathrm{SL}$ separated young-of-the-year (Age-0) and older (Age$1+$ ) pollock, and enabled separation of age groups in subsequent analyses.

The geographic distribution of Age- 0 walleye pollock was broader and more variable from year to year than that of Age-1+ individuals. Both groups tended to concentrate in the NEin area (Fig. 6), but the area-year interaction was significant in both ANOVA tests (Table 5). For Age-0 fish, high mean population densities were encountered during the low-flow year in the SWmid area; for Age-1+ fish, low densities were observed in all areas during 2003 (Fig. 6). For both groups, sampling at night produced higher population density estimates than sampling during the day.

Mean length of Age-0 and Age-1+ walleye pollock tended to increase shoreward. Mean length for Age-0 fish was highest northeast; for Age-1+ fish, mean length was highest in the SWin area (Fig. 7). However, ANOVA test results (Table 5) indicated significant 3-way interaction among year, diel, and area effects on Age-0 mean length, and no significant area effect on Age-1+ length means, which increased from 2000 to 2003.

\section{Capelin}

Capelin (57 to 128 mm SL; Fig. 5) were variably distributed over the shelf, but high concentrations were encountered at night in the relatively fresh, warm, low-flow, SWin area (Fig. 6). Consequently, the area effect was significant only among nighttime collections (Table 5). On average, capelin collected at night were small relative to those collected during the day, hence, the significant diel effect (Table 5). Geographically, 

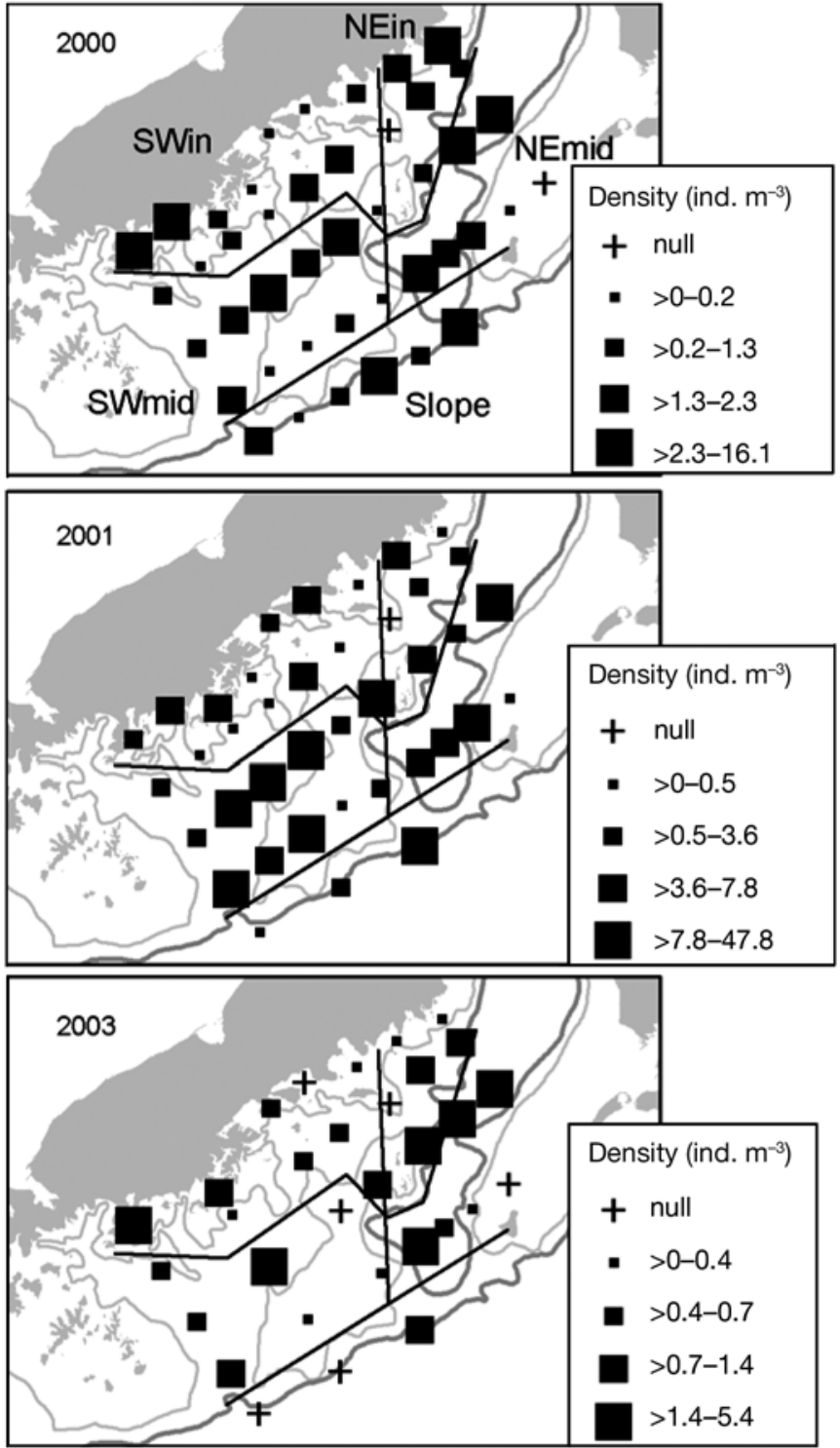

Fig. 4. Geographic distribution of krill population density during September 2000, 2001, and 2003 from samples collected at night. In each panel, symbol type distinguishes null and non-null catches. Size of symbols representing non-null catches indicates population density. Solid black lines depict the hydrographic-based geographic areas. Thin/thick gray lines: 100/200 $\mathrm{m}$ isobaths, respectively

capelin in the SWin area tended to be relatively small (Fig. 7), but the area-year interaction was significant (Table 5).

\section{Eulachon}

Eulachon (58 to $205 \mathrm{~mm}$ SL) exhibited a multi-modal frequency distribution (Fig. 5), but size-specific analysis was not supported by clear separation of age groups. Each year, eulachon were concentrated north-
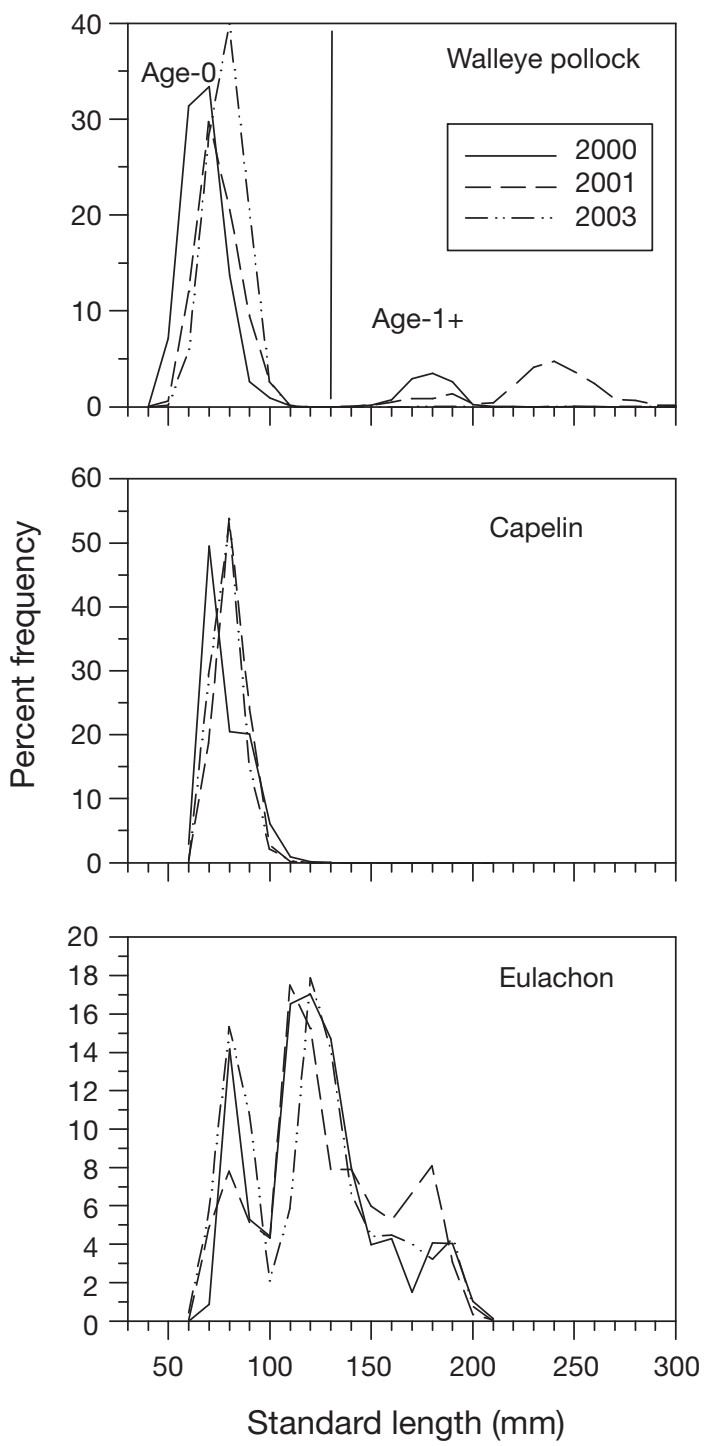

Fig. 5. Theragra chalcogramma, Mallotus villosus, Thaleichthys pacificus. Size composition of walleye pollock, capelin, and eulachon collected in the western Gulf of Alaska during September 2000, 2001, and 2003. Vertical bar at $130 \mathrm{~mm}$ standard length delineates Age-0 and Age-1+ walleye pollock

east, especially in the NEin area (Fig. 6). Population density increased from 2000 to 2003, and was highest at night, but these effects did not interact with the significant area effect (Table 5). As for capelin, eulachon in the SWin area were, on average, smaller than eulachon collected elsewhere (Fig. 7); the area effect was significant (Table 5).

\section{Fish-zooplankton correlation}

Each year, population densities of Age-1+ walleye pollock and eulachon increased with krill density 
Table 4. Taxonomic composition of midwater trawl catches collected from the upper $200 \mathrm{~m}$ depth in the western Gulf of Alaska during September 2000, 2001, and 2003. The targeted species, walleye pollock Theragra chalcogramma, capelin Mallotus villosus, and eulachon Thaleichthys pacificus, are in bold.

Note that density (ind. $\mathrm{m}^{-3}$ ) has been multiplied by $10^{6}$. NA: not available

\begin{tabular}{|c|c|c|c|c|}
\hline Taxonomic group & $\begin{array}{c}\text { Frequency of } \\
\text { occurrence } \\
(\%)\end{array}$ & $\begin{array}{l}\text { Density } \\
\left(\text { ind. } \mathrm{m}^{-3} \text { ) }\right. \\
\times 10^{6}\end{array}$ & $\begin{array}{l}\text { Biomass } \\
\left(\mathrm{mg} \mathrm{m}^{-3}\right)\end{array}$ & $\begin{array}{c}\text { Ind. } \\
\text { weight } \\
\left(\mathrm{g} \text { ind. }{ }^{-1}\right)\end{array}$ \\
\hline Scyphozoa, large ${ }^{a}$ & 97.9 & 109.652 & 78.037 & 711.7 \\
\hline Scyphozoa, other & 94.9 & 183.529 & 38.944 & 212.2 \\
\hline Theragra chalcogramma, Age-0 & $\mathbf{- 0} \quad 71.9$ & 733.157 & 2.532 & 3.5 \\
\hline Mallotus villosus & 54.0 & 399.610 & 1.421 & 3.6 \\
\hline Theragra chalcogramma, Age-1 & $-1+44.7$ & 111.095 & 15.850 & 142.7 \\
\hline Thaleichthys pacificus & 39.1 & 85.718 & 1.710 & 20.0 \\
\hline Atheresthes stomias & 38.3 & 13.036 & 3.492 & 267.8 \\
\hline Stichaeidae & 30.2 & 300.052 & 0.026 & 0.1 \\
\hline Teleostei & 27.7 & 5091.420 & 0.653 & 0.1 \\
\hline Salmonidae & 27.7 & 4.559 & 0.342 & 75.1 \\
\hline Scorpaenidae & 15.3 & 1.487 & 0.091 & 61.4 \\
\hline Ammodytidae & 14.0 & 48.561 & 0.071 & 1.5 \\
\hline Gadidae & 11.9 & 1.978 & 0.573 & 289.7 \\
\hline Zaproridae & 11.9 & 0.798 & 0.056 & 70.0 \\
\hline Myctophidae & 11.1 & 3.450 & 0.003 & 0.8 \\
\hline Trichodontidae & 8.9 & 4.441 & 0.182 & 41.0 \\
\hline Bathymasteridae & 8.1 & 1.133 & $<0.001$ & 0.3 \\
\hline Clupeidae & 6.8 & 10.662 & 0.057 & 5.3 \\
\hline Pleuronectidae & 6.8 & 1.096 & 0.5452 & 497.0 \\
\hline Cottidae & 6.0 & 0.720 & 0.009 & 12.1 \\
\hline Cyclopteridae & 4.7 & 0.280 & 0.081 & 289.1 \\
\hline Liparididae & 3.4 & 0.268 & $<0.001$ & 0.8 \\
\hline Anoplopomatidae & 1.7 & 0.129 & 0.059 & 459.3 \\
\hline Agonidae & 1.3 & 0.079 & 0.001 & 14.3 \\
\hline Gasterosteidae & 0.9 & 0.074 & $<0.001$ & 0.5 \\
\hline Bathylagidae & 0.9 & 0.032 & $<0.001$ & 3.3 \\
\hline Hexagrammidae & 0.9 & 0.031 & 0.003 & 96.2 \\
\hline Macrouridae & 0.4 & 0.074 & 0.273 & 3700.0 \\
\hline Rajidae & 0.4 & 0.022 & 0.263 & 12200.0 \\
\hline Zoarcidae & 0.4 & 0.020 & $<0.001$ & 3.0 \\
\hline Squalidae & 0.4 & 0.015 & 0.705 & 46400.0 \\
\hline Lamnidae & 0.4 & 0.012 & NA & NA \\
\hline Grand total & 100.0 & 7107.191 & 145.980 & 20.5 \\
\hline
\end{tabular}

net current velocity estimates (Fig. 8). Each year, relatively high fish population densities were located over the shelf, where mean daily velocity exceeded $5 \mathrm{~cm} \mathrm{~s}^{-1}$ and where krill were concentrated. Fish-krill aggregations were widespread in the Shelikof sea valley vicinity. Eulachon were especially concentrated along the western, near-shore margin of the Shelikof sea valley.

\section{DISCUSSION}

Meso-scale geographic patterns in the physical environment were consistent with previous observations (Schumacher \& Reed 1986) and were associated with zooplankton and fish distributions. Near shore, the water was relatively warm, fresh, and contained high densities of crab and fish larvae (Figs. 2 \& 3). Warm water may benefit larvae by promoting rapid growth, which would accelerate the recruitment process. The concentration of larvae near shore could reflect enhanced retention, adult spawning strategy, or reduced mortality. Certainly, crab larvae are well known for vertically migrating between depth layers of different current directions to enhance retention near shore (Shanks 1995, Queiroga et al. 2006). The low salinity observed near shore, indicative of the ACC (Schumacher \& Reed 1986), might help form the requisite vertically stratified flow field. However, unprotected

across sites. Spearman coefficients for Age-1+ walleye pollock-krill correlation ( $\mathrm{r} \geq 0.51$ ) during 2000 (day), 2001 (night), and 2003 (day, night) were significant ( $\mathrm{p}$ 0.003, Bonferroni corrected). Similarly, eulachon-krill correlation ( $\mathrm{r} \geq 0.41$ ) during 2000 (day), 2001 (day), and 2003 (day, night) were significant $(\mathrm{p}<0.008$, Bonferroni corrected). Other fish-zooplankton correlations involved large copepods and chaetognaths, but only in 3 diel-year combinations. Possible avoidance of larvaceans by eulachon and capelin was suggested by the negative correlation $(\mathrm{r} \leq-0.45, \mathrm{p}<0.005)$ in population densities. Larvaceans, a gelatinous zooplankter, were the only potential prey group for which the density was inversely related to fish density.

Population densities of krill and Age-1+ pollock or eulachon were associated with geographic variation in exposure to the ACC could adversely affect retention. The SWin area, where crab larvae were densest, was relatively well protected from along-shore flow by Sutwik Island and Semidi Bank. Furthermore, larval crab density was high during the relatively low-flow year 2000. For fish larvae, most of which were osmerids (Lanksbury et al. 2005), adult spawning location likely promoted the relatively high, near-shore population densities. Although not identified to species, the only post-larval osmerids collected in the study area were capelin Mallotus villosus and eulachon Thaleichthys pacificus. Capelin spawn near shore (Pahlke 1985), and eulachon are anadromous (Hay \& McCarter 2000) and are known to spawn in rivers emptying into the study area (Willson et al. 2006). The concentration of fish larvae near shore is therefore consistent with 

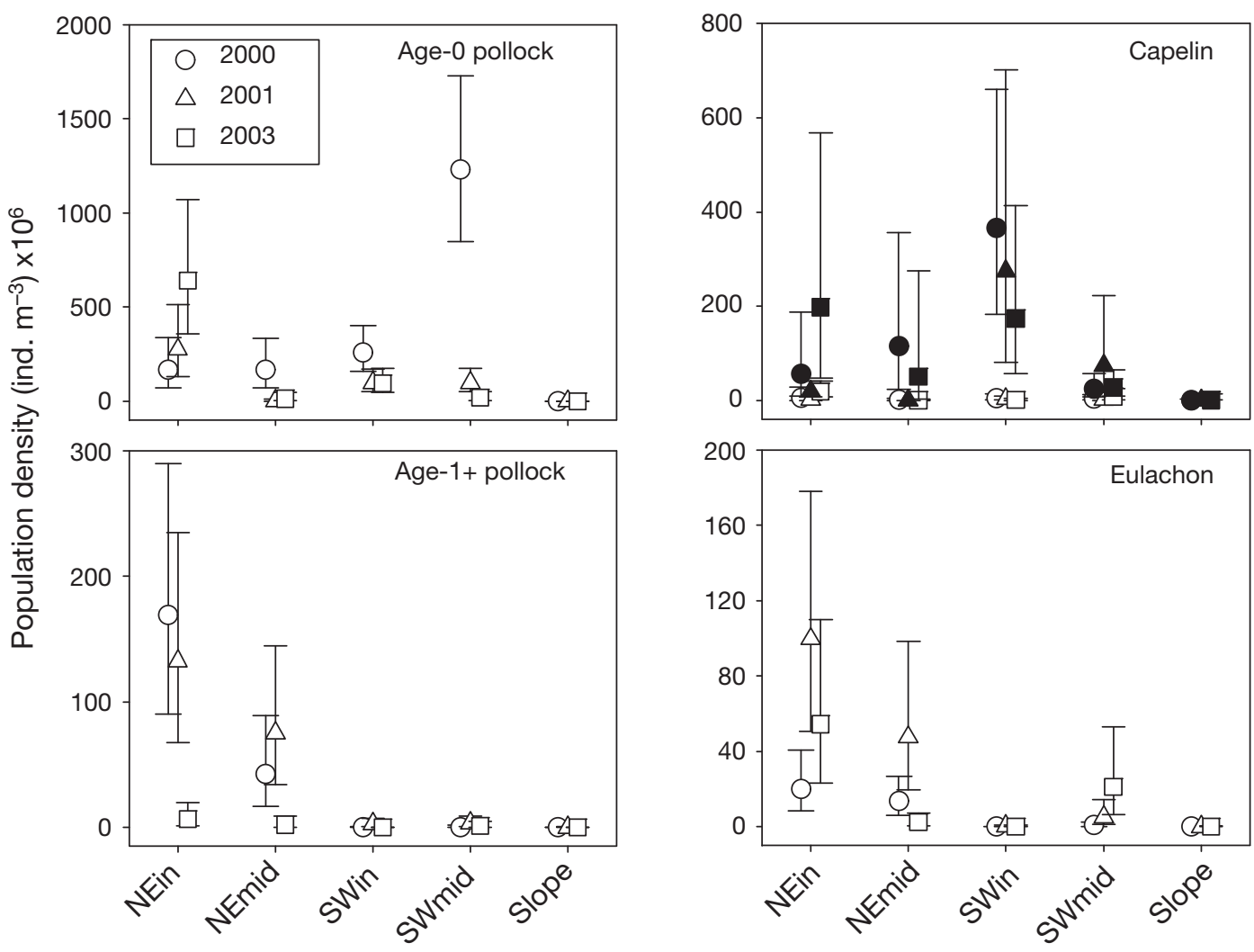

Fig. 6. Theragra chalcogramma, Mallotus villosus, Thaleichthys pacificus. Back-transformed mean $( \pm 1$ SE) population density (ind. $\mathrm{m}^{-3}$ ) of fish collected in 5 geographic areas in the western Gulf of Alaska during September 2000, 2001, and 2003. For capelin, symbols are further differentiated by diel period (open symbols: day; filled symbols: night) due to the significant diel-area interaction (see Table 5). Note that density estimates have been multiplied by $10^{6}$

Table 5. Theragra chalcogramma, Mallotus villosus, Thaleichthys pacificus. Significance ( $p$-values) of terms retained in reduced models from analysis of variance of year, diel, and area effects on fish population density and mean individual length. One test was conducted for each of the 4 fish groups. Dashes indicate non-significant $(p>0.05)$ terms eliminated during model reduction

\begin{tabular}{|lccccc|}
\hline $\begin{array}{l}\text { Dependent } \\
\text { variable }\end{array}$ & $\begin{array}{c}\text { Reduced model } \\
\text { term }\end{array}$ & \multicolumn{2}{c}{ Walleye pollock } & Capelin & Eulachon \\
\hline Population density & Yge-0 & Age-1+ & & \\
& Diel & 0.001 & $<0.001$ & - & 0.002 \\
& Area & $<0.001$ & 0.001 & $<0.001$ & 0.003 \\
& Year-Area & $<0.001$ & 0.001 & 0.005 & $<0.001$ \\
& Diel-Area & - & - & 0.001 & - \\
Mean length & $<0.001$ & $<0.001$ & 0.208 & - \\
& Year & 0.314 & - & $<0.001$ & - \\
& Diel & 0.004 & - & 0.074 & 0.006 \\
& Area & 0.061 & - & - & - \\
& Year-Diel & $<0.001$ & - & $<0.001$ & - \\
& Year-Area & 0.058 & - & - & - \\
& Diel-Area & 0.001 & - \\
& Year-Diel-Area & 0.005 & - & - & - \\
\hline
\end{tabular}

the preponderance of osmerid larvae in the collections and the coastal spawning habits of capelin and eulachon. Thus, species-specific retention mechanisms can explain the high density of crab and fish larvae near shore. Successful retention, however, also ap- pears to depend on reduced near-shore flow.

Geographic distributions of mean length suggest that capelin and eulachon differ from walleye pollock Theragra chalcogramma in their utilization of near-shore areas. For capelin and eulachon, mean length distributions were consistent with size-related movements away from a near-shore nursery (SWin; Fig. 7). In contrast, Age-0 and Age-1+ walleye pollock mean lengths were consistent with size-related movement into near-shore areas; however, distinguishing this from differences in site-specific growth or size-selective mortality is difficult. Age-0 walleye pollock consume crab larvae (Wilson et al. 2006), which are an energyrich prey (Mazur et al. 2007), and Age-1+ walleye pollock consume small fishes (Yang et al. 2006). It is unclear whether predation threats contribute to the movement of capelin and eulachon from near-shore nurseries. 

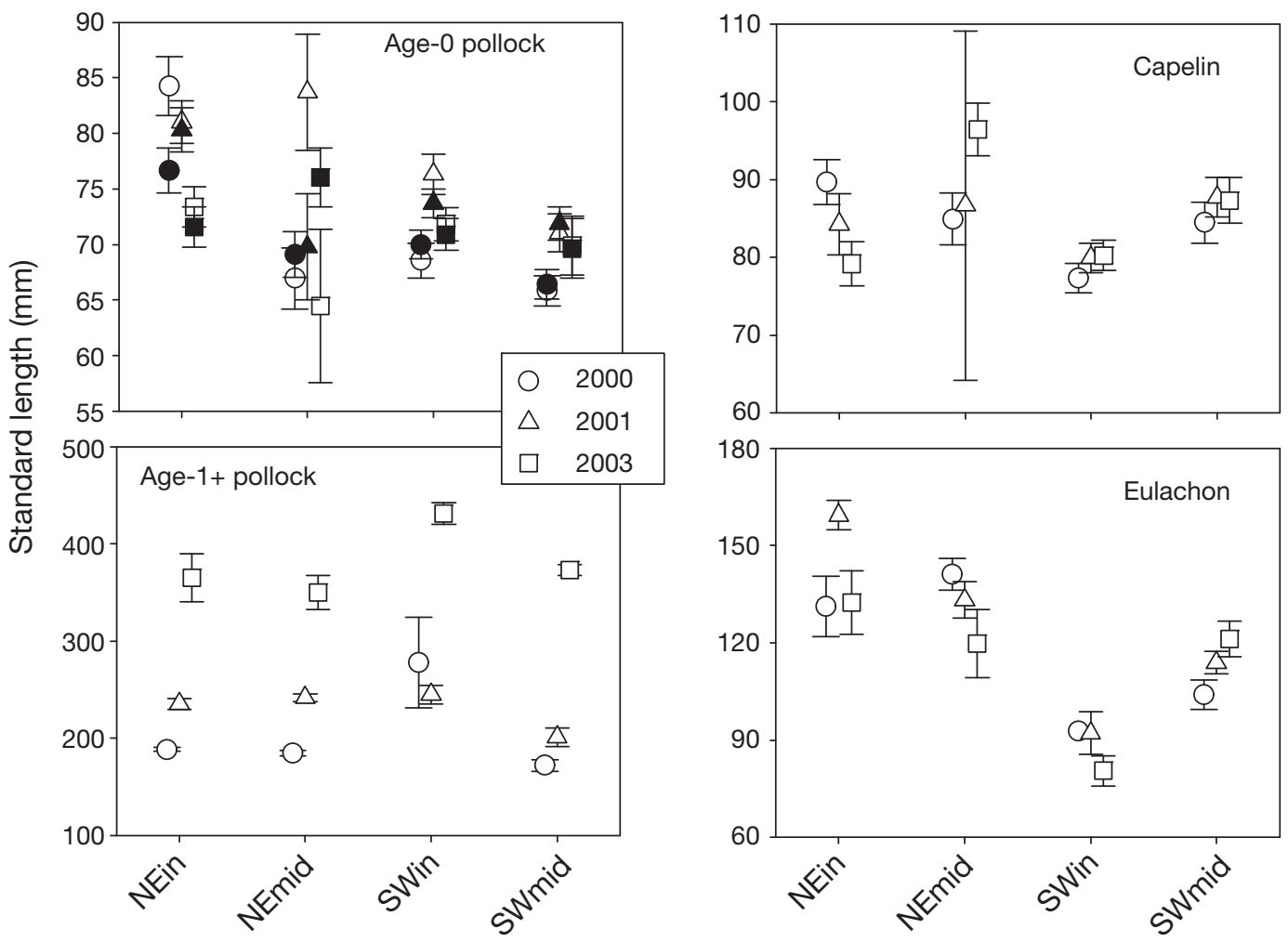

Fig. 7. Theragra chalcogramma, Mallotus villosus, Thaleichthys pacificus. Population mean standard length $( \pm 1$ SE) of fish collected in 4 geographic areas over the shelf in the western Gulf of Alaska during September 2000, 2001, and 2003. For Age-0 pollock, symbols are further differentiated by diel period (open symbols: day; filled symbol: night) due to the significant year-diel-area interaction (see Table 5)

Over the shelf, Age-1+ walleye pollock and eulachon aggregated with krill in relatively high-flow areas associated with sea valleys (Fig. 8). Fish-zooplankton aggregations are often associated with bathymetric features and result from interaction between animal behavior and ocean currents (Genin 2004). Wilson et al. (2009) showed that Age-1+ walleye pollock and eulachon fed primarily on krill. In the Shelikof sea valley, krill may be concentrated by up-slope flow as ACC water moves over the western margin (Koslow \& Ota 1981, Schumacher \& Reed 1986, Napp et al. 1996). Concentrations of krill in Nitinat Canyon (British Columbia, Canada) were attributed by Mackas et al. (1997) to active swimming against up-slope flow to maintain position at preferred isolumes. A similar mechanism may operate in the Shumagin sea valley (Fig. 4), but the process may depend more on tidal forcing (e.g. Cotté \& Simard 2005) than on net current velocity, which was low relative to the Shelikof sea valley (Fig. 2).

Krill inputs to the Shelikof-Shumagin area may depend on along-shelf flux and influxes of slope water. The main krill species collected within the study area, Thysaneossa inermis, also occurs upstream in the northern GOA, where late-summer maximum densi- ties (ca. 0.3 ind. $\mathrm{m}^{-3}$ ) occur over the inner shelf (Coyle $\&$ Pinchuk 2005). The inner shelf is flushed by the ACC (Weingartner et al. 2005). Typical near-surface velocities of the ACC during late summer are high (Stabeno et al. 2004) relative to krill routine swimming speed, which was estimated to be 1 to $3.5 \mathrm{~cm} \mathrm{~s}^{-1}$ for adult T. inermis (De Robertis et al. 2003). Furthermore, atdepth influxes of oceanic water (Stabeno et al. 2004) may transport krill from the slope onto the shelf. It is significant that during 2001, when net current velocity was high, strong recruitment of small krill was observed in the study area (Wilson et al. 2009). Small krill are especially susceptible to advection in near-surface flow (Lu et al. 2003). Thus, while the distribution of krill within the study area adhered to a fixed geographic template, which apparently was exploited by Age-1+ walleye pollock and eulachon, the process of krill inputs appears to vary with ACC flow.

In contrast to Age-1+ walleye pollock and eulachon, the geographic distributions of Age- 0 walleye pollock and capelin densities varied from year-to-year (Fig. 6). The relatively small size of these fishes (Fig. 7) may translate into greater susceptibility to net transport. For Age-0 walleye pollock, this was suggested by upstream-related increases in mean body size; however, 


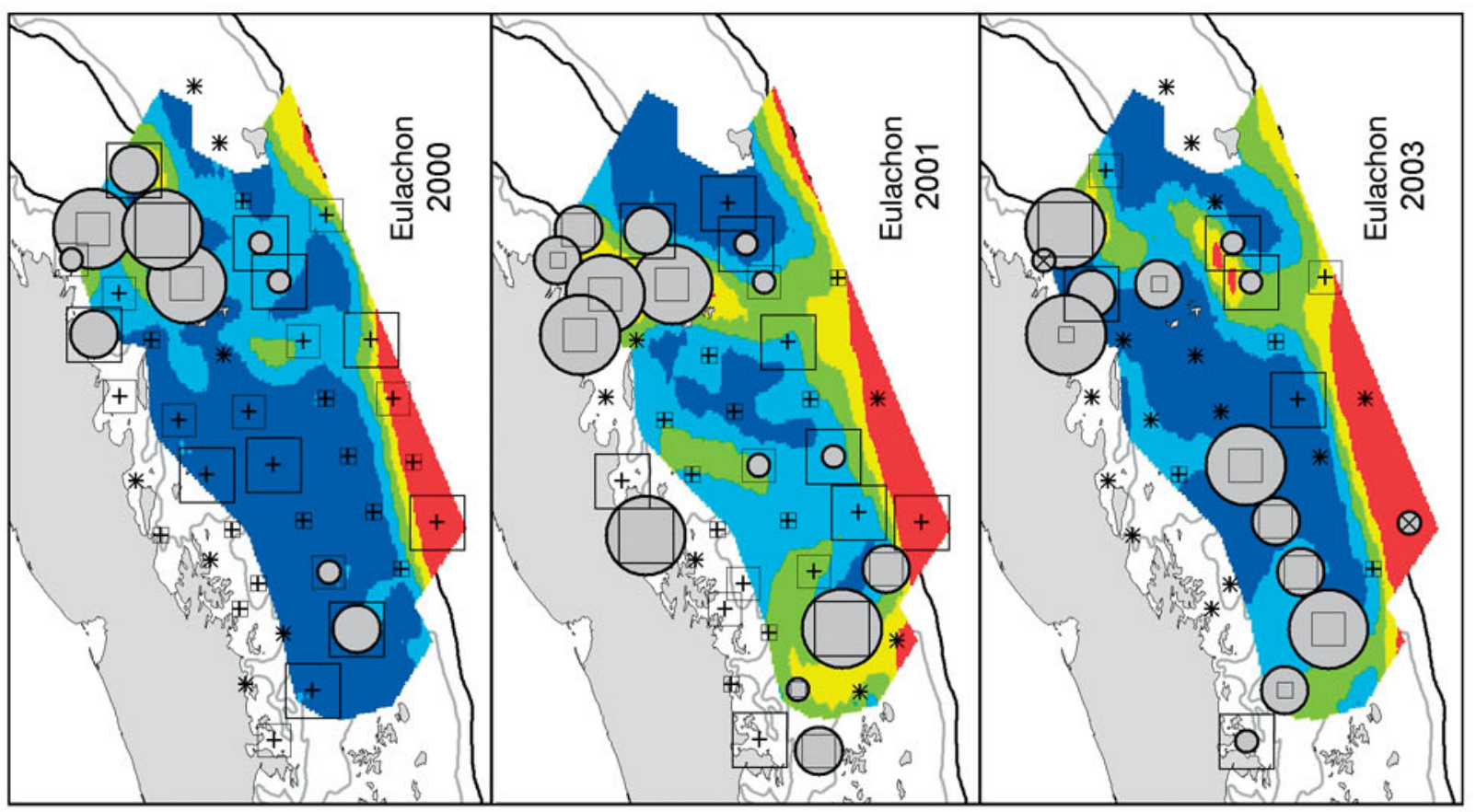

d)

월

政

जै

ฮี ฮี

Ta

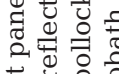

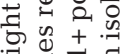

동

茫

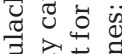

(1) ज्ञ

क

ब.

2, 죽

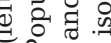

굴

긍

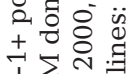

近国

马

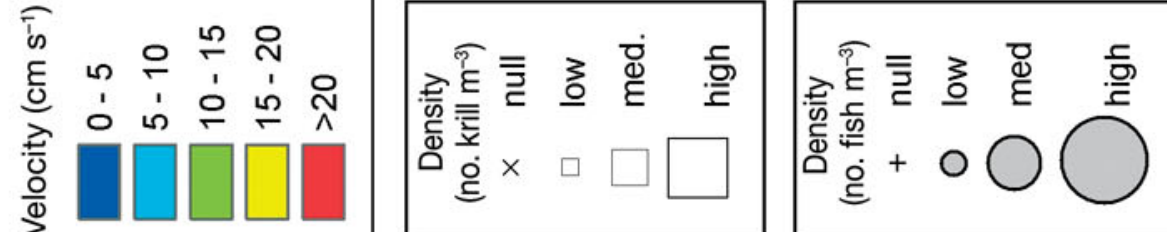

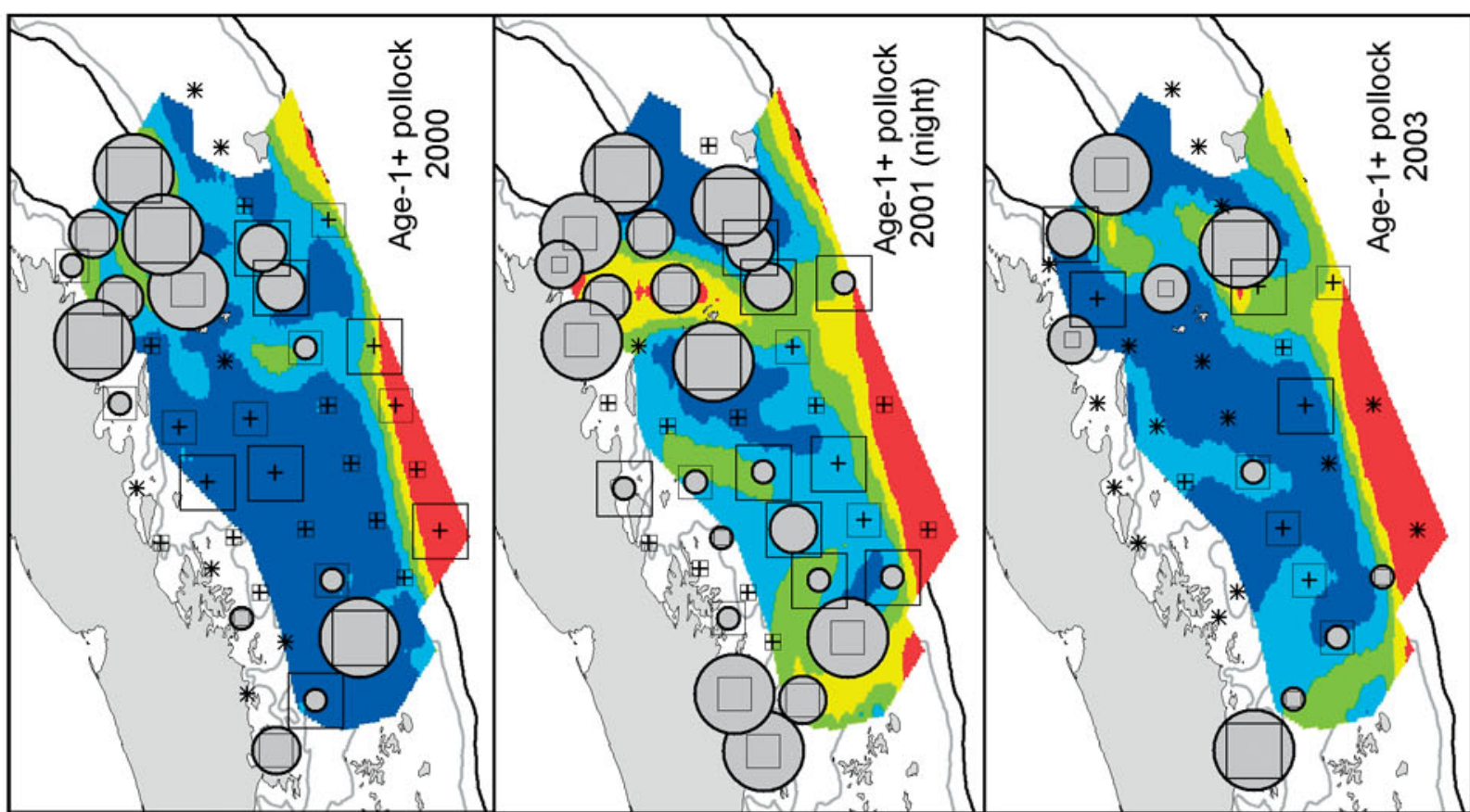

켱 ᅰ

누요.

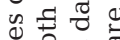

㻤密要

षै

a 3

进

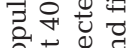

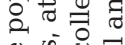

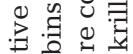

ब

둉

的考

열

2. 㟧

논웡ㅊㄹ

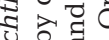

ฮี ซ్

₹ ㄱ.

व

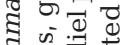

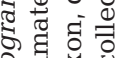

एक

वृ

\%

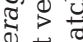

돌

$\infty$ 흥

雨 
admittedly, thermal effects on growth rate could not be excluded. Another consideration is that Age- 0 walleye pollock and capelin may be constrained by size from full access to the krill resource. For both species, consumption of krill increased with predator length (Wilson et al. 2009). Predator length is a proxy for mouth gape width (Brodeur 1998). These fishes, especially the smallest individuals, consumed smaller prey including copepods, which were more evenly distributed than krill throughout the study area and whose ubiquitous availability may have reduced predator impetus to search for krill. With growth, these fishes may increasingly exploit krill in high-flow areas due to enhanced swimming abilities and changed dietary preferences.

Beyond the shelf, the paucity of walleye pollock, capelin, and eulachon may reflect behavioral avoidance of or inability to accumulate in the relatively cool, swift-flowing Alaskan Stream (Figs. 2 \& 6). For Age-0 pollock, water temperature over the slope was furthest from their 10 to $13^{\circ} \mathrm{C}$ thermal optimum (Ciannelli et al. 1998). Furthermore, the cruise speeds of 1 to 2 body length $\mathrm{s}^{-1}$ for Age- 0 walleye pollock (Ryer et al. 2002) are not sufficient to maintain position in the typical 30 to $40 \mathrm{~cm} \mathrm{~s}^{-1}$ flow of the Alaskan Stream. Little is known about the thermal preferences and swimming abilities of older walleye pollock, capelin, and eulachon; however, given the observed body lengths, individuals would have to be properly oriented and cruise at speeds considerably higher than 1 body length $\mathrm{s}^{-1}$ to maintain position in the Alaskan Stream.

Using 1 gear type to accurately assess the density of the entire zooplankton community is difficult due to variability in animal body size, swimming ability, vertical migration behavior, and degree of damage within nets. Miller et al. (1984) demonstrated that $333 \mu \mathrm{m}$ mesh does not retain early copepodite stages of Neocalanus plumchrus, with maximum cephalothorax widths of $<344 \mu \mathrm{m}$. In fact, EcoFOCI's routine zooplankton collections enumerate all of the small copepods from $153 \mu \mathrm{m}$, not $333 \mu \mathrm{m}$, mesh nets (Incze et al. 1997). The strong swimming ability and diel vertical migration of krill may have also resulted in underestimates of population density due to net avoidance or movement during the day to below the sample depth (Shaw \& Robinson 1998). In the present study, the overall mean population density of krill from samples collected during the day $\left(0.2 \mathrm{~m}^{-3}\right)$ was considerably less than the estimate from night sampling $\left(1.2 \mathrm{~m}^{-3}\right)$, which was within the range of other estimates from north temperate regions as reviewed by Siegel (2000). Such sampling biases can distinctly affect apparent distribution patterns of population density. However, for krill, lack of significant interaction between the diel and area effects suggests that any diel-related sam- pling bias did not alter the observed distribution of krill population density.

Computation of fish population density did not account for local current direction, because flow through the trawl was not measured. Towing the trawl into the current between fixed geographic points would, for example, filter more water than if towed with the current. Concentration of Age-1+ walleye pollock and eulachon in high-flow areas might therefore reflect a systematic bias in relative tow direction. However, tow direction was usually oriented into the wind (calm seas were exceptional), which was similarly directed for days on end. Water flow, in contrast, flows over the western GOA shelf with much directional variability due to eddies, tides, topographic effects, and vertical sheer (Stabeno et al. 2004). Furthermore, no other trawl-caught animals, including the ubiquitously distributed large scyphozoans (unpubl. data), were concentrated in high-flow areas. Thus, while tow direction relative to current direction is an important sampling consideration, it seems unlikely that the observed concentrations of fish in high-flow shelf areas reflect a systematic bias in relative tow direction.

In conclusion, the western GOA neritic environment was geographically structured by salinity, temperature, and net current velocity. Near shore, concentrations of crab and fish larvae presumably reflect effective, species-specific retention mechanisms that counter dispersion by coastal currents. The shoreward increase in walleye pollock mean length suggests some benefit from the concentrations of prey (crab larvae and small fishes) and warm water near shore, but this was not associated with increased population density. In contrast, over the shelf, walleye pollock (Age-1+) and eulachon were aggregated with krill in relatively high-flow areas associated with sea valleys. Consistency in year-to-year location of these aggregations suggests an important bathymetric effect on aggregation formation. While this supports Cooney's (1986) hypothesis that the physical environment (bathymetry, ocean currents) plays an important role in facilitating local accumulations of zooplankton and zooplanktivores in the GOA, the underlying mechanism and its resilience to climate variability is unknown. Age-0 walleye pollock and capelin were not similarly aggregated due perhaps to less well-developed swim abilities and different dietary preferences. Over the slope, the relatively cold temperature and rapid flow of Alaskan Stream water may act as a barrier to offshore dispersal of walleye pollock, capelin, and eulachon. While these results provide some resolution of physical-biological processes in the GOA coastal ecosystem, more work is needed to identify specific small-scale processes and to further investigate the apparent resilience of the observed geographic structure to interannual variation in the physical environment. 
Acknowledgements. J. Napp and K. Bailey provided program support and helped guide the scope of this project. K. Mier provided much statistical advice and assistance. A. Dougherty, and S. Porter provided much at-sea and in-laboratory assistance. B. Rugen and C. Harpold helped prepare the plankton data for analyses. A. Hermann and L. Dobbins kindly provided and discussed SPEM output. Thanks also to the captain and crew of the NOAA ship 'Miller Freeman'. J. Clark, the AFSC Research Fishing Gear Program, and the MACE Program provided gear. Comments from M. Dorn, J. Duffy-Anderson, L. Logerwell, S. Picquelle, J. Napp, the AFSC Publications Unit, and 5 anonymous reviewers improved the manuscript. This research is Contribution EcoFOCI-R686 to NOAA's Ecosystems and Fisheries-Oceanography Coordinated Investigations, and (NPRB) Publ. No. 228 to North Pacific Research Board. Support for this research was provided by the Sea Lion Research Initiative (Grant No. 02FF04), and the North Pacific Research Board (Grant No. R0308).

\section{LITERATURE CITED}

Bailey KM, Brown AL, Yoklavich MM, Mier KL (1996) Interannual variability in growth of larval and juvenile walleye pollock Theragra chalcogramma in the western Gulf of Alaska, 1983-91. Fish Oceanogr 5(Suppl 1):137-147

Brodeur RD (1998) Prey selection by age-0 walleye pollock, Theragra chalcogramma, in nearshore waters of the Gulf of Alaska. Environ Biol Fishes 51:175-186

Brodeur RD, Wilson MT (1996) A review of the distribution, ecology and population dynamics of age- 0 walleye pollock in the Gulf of Alaska. Fish Oceanogr 5(Suppl 1): 148-166

Buchheister A, Wilson MT (2005) Shrinkage correction and length conversion equations for Theragra chalcogramma, Mallotus villosus, and Thaleichthys pacificus. J Fish Biol 67:541-548

> Ciannelli L, Brodeur RD, Buckley TW (1998) Development and application of a bioenergetics model for juvenile walleye pollock. J Fish Biol 52:879-898

Cochran WG (1977) Sampling techniques, 3rd edn. John Wiley \& Sons, New York

Cooney RT (1986) Zooplankton. In: Hood DW, Zimmerman ST (eds) The Gulf of Alaska physical environment and biological resources. Ocean Assessment Division, NOAA, Washington, DC, p 285-303

> Cotté C, Simard Y (2005) Formation of dense krill patches under tidal forcing at whale feeding hot spots in the St. Lawrence Estuary. Mar Ecol Prog Ser 288:199-210

Coyle KO, Pinchuk AI (2003) Annual cycle of zooplankton abundance, biomass and production on the northern Gulf of Alaska shelf, October 1997 through October 2000. Fish Oceanogr 12:327-338

Coyle KO, Pinchuk AI (2005) Seasonal cross-shelf distribution of major zooplankton taxa on the northern Gulf of Alaska shelf relative to water mass properties, species depth preferences and vertical migration behavior. Deep-Sea Res II 52:217-245

De Robertis A, Schell C, Jaffe JS (2003) Acoustic observations of the swimming behavior of the euphausiid Euphausia pacifica Hansen. ICES J Mar Sci 60:885-898

Fréon P, Cury P, Shannon L, Roy C (2005) Sustainable exploitation of small pelagic fish stocks challenged by environmental and ecosystem changes: a review. Bull Mar Sci 76:385-462

Genin A (2004) Bio-physical coupling in the formation of zooplankton and fish aggregations over abrupt topographies. J Mar Syst 50:3-20
Gjøsæter H (1998) The population biology and exploitation of capelin (Mallotus villosus) in the Barents Sea. Sarsia 83: 453-496

Hay D, McCarter PB (2000) Status of the eulachon Ithaleichthys pacificus in Canada. Res Doc 2000-145, Department of Fisheries and Oceans Canada, Canadian Stock Assessment Secretariat, Ottawa

Helle K, Pennington M (1999) The relation of the spatial distribution of early juvenile cod (Gadus morhua L.) in the Barents Sea to zooplankton density and water flux during the period 1978-1984. ICES J Mar Sci 56:15-27

- Hermann AJ, Stabeno PJ (1996) An eddy-resolving model of circulation on the western Gulf of Alaska shelf. 1. Model development and sensitivity analysis. J Geophys Res 101(C1):1129-1149

> Hinckley S, Bailey KM, Picquelle SJ, Schumacher JD, Stabeno PJ (1991) Transport, distribution, and abundance of larval and juvenile walleye pollock (Theragra chalcogramma) in the western Gulf of Alaska. Can J Fish Aquat Sci 48:91-98

> Honda S, Oshima T, Nishimura A, Hattori T (2004) Movement of juvenile walleye pollock, Theragra chalcogramma, from a spawning ground to a nursery ground along the Pacific coast of Hokkaido, Japan. Fish Oceanogr 13(Suppl 1): $84-98$

Incze LS, Siefert DW, Napp JM (1997) Mesozooplankton of Shelikof Strait, Alaska: abundance and community composition. Cont Shelf Res 17:287-305

> Iverson SJ, Frost KJ, Lang SLC (2002) Fat content and fatty acid composition of forage fish and invertebrates in Prince William Sound, Alaska: factors contributing to among and within species variability. Mar Ecol Prog Ser 241:161-181

Kendall AW Jr, Schumacher JD, Kim S (1996) Walleye pollock recruitment in Shelikof Strait: applied fisheries oceanography. Fish Oceanogr 5(Suppl 1):4-18

Koslow JA, Ota A (1981) The ecology of vertical migrators in the La Jolla Bight, April-August, 1967. Biol Oceanogr $1: 107-134$

Lanksbury JA, Duffy-Anderson JT, Mier KL, Wilson MT (2005) Ichthyoplankton abundance, distribution, and assemblage structure in the Gulf of Alaska during September 2000 and 2001. Estuar Coast Shelf Sci 64: 775-785

> Lu B, Mackas DL, Moore DF (2003) Cross-shore separation of adult and juvenile euphausiids in a shelf-break alongshore current. Prog Oceanogr 57:381-404

> Mackas DL, Kieser R, Saunders M, Yelland DR, Brown RM, Moore DF (1997) Aggregation of euphausiids and Pacific hake (Merluccius productus) along the outer continental shelf off Vancouver Island. Can J Fish Aquat Sci 54: 2080-2096

Mann KH, Lazier JRN (2006) Dynamics of marine ecosystems: biological-physical interactions in the oceans. Blackwell Publishing, Malden, MA

Mazur MM, Wilson MT, Dougherty AB, Buchheister A, Beauchamp DA (2007) Temperature and prey quality effects on growth of juvenile walleye pollock (Theragra chalcogramma): a spatially explicit bioenergetics approach. J Fish Biol 70:816-836

> Miller CB, Frost BW, Batchelder HP, Clemons MJ, Conway RE (1984) Life histories of large, grazing copepods in a subarctic ocean gyre: Neocalanus plumchrus, Neocalanus cristatus, and Eucalanus bungii in the Northeast Pacific. Prog Oceanogr 13:201-243

Milliken GA, Johnson DE (1996) Analysis of messy data, Vol I. Designed experiments. Chapman \& Hall, London 
Napp JM, Incze LS, Ortner PB, Siefert DLW, Britt L (1996) The plankton of Shelikof Strait, Alaska: standing stock, production, mesoscale variability and their relevance to larval fish survival. Fish Oceanogr 5(Suppl 1):19-38

Pahlke KA (1985) Life history and distribution of capelin, Mallotus villosus, in Alaskan waters. MS thesis, University of Alaska, Juneau, AK

Queiroga H, Almeida MJ, Alpuim T, Flores AAV and others (2006) Tide and wind control of megalopal supply to estuarine crab populations on the Portuguese west coast. Mar Ecol Prog Ser 307:21-36

Reed RK, Schumacher JD (1986) Physical oceanography. In: Hood DW, Zimmerman ST (eds) The Gulf of Alaska: physical environment and biological resources. Ocean Assessment Division, NOAA, Washington, DC, p 57-75

Ryer CH, Lawton A, Lopez RJ, Olla BL (2002) A comparison of the functional ecology of visual vs. nonvisual foraging in two planktivorous marine fishes. Can J Fish Aquat Sci 59:1305-1314

Schumacher JD, Reed RK (1986) On the Alaska Coastal Current in the western Gulf of Alaska. J Geophys Res 91(C8):9655-9661

Shanks AL (1995) Mechanisms of cross-shelf dispersal of larval invertebrates and fish. In: McEdward LR (ed) Ecology of marine invertebrate larvae. CRC Press, Boca Raton, FL, p 323-367

Shaw W, Robinson CLK (1998) Night versus day abundance estimate of zooplankton at two coastal stations in British Columbia, Canada. Mar Ecol Prog Ser 175:143-153

Siefert DW, Incze LS (1991) Zooplankton of Shelikof Strait, Alaska, April and May 1989: data from Fisheries Oceanography Coordinated Investigations (FOCI) cruises. NOAA AFSC Proc Rep 91-16, US Dept of Commerce, Alaska Fisheries Science Center, National Marine Fisheries Service, Seattle, WA

Siegel V (2000) Krill (Euphausiacea) demography and variability in abundance and distribution. Can J Fish Aquat Sci 57(Suppl 3):151-167

Stabeno PJ, Hermann AJ (1996) An eddy-resolving model of

Editorial responsibility: Hans Heinrich Janssen, Oldendorf/Luhe, Germany circulation on the western Gulf of Alaska shelf. 2. Comparison of results to oceanographic observations. J Geophys Res 101(C1):1151-1161

> Stabeno PJ, Bond NA, Hermann AJ, Kachel NB, Mordy CW, Overland JE (2004) Meteorology and oceanography of the northern Gulf of Alaska. Cont Shelf Res 24:859-897

> Weingartner TJ, Danielson SL, Royer TC (2005) Freshwater variability and predictability in the Alaska Coastal Current. Deep-Sea Res II 52: 169-191

Willson MF, Armstrong RH, Hermans MC, Koski K (2006) Eulachon: a review of biology and an annotated bibliography. NOAA AFSC Proc Rep 2006-12, Auke Bay Laboratory, Alaska Fisheries Science Center, NOAA, National Marine Fisheries Service, Juneau, AK

Wilson MT, Brodeur RD, Hinckley S (1996) Distribution and abundance of age-0 walleye pollock, Theragra chalcogramma, in the western Gulf of Alaska during September 1990. NOAA AFSC Tech Rep 126, US Dept of Commerce, Alaska Fisheries Science Center, National Marine Fisheries Service, Seattle, WA, p 11-24

Wilson MT, Jump CM, Duffy-Anderson JT (2006) Comparative analysis of the feeding ecology of two pelagic forage fishes: capelin Mallotus villosus and walleye pollock Theragra chalcogramma. Mar Ecol Prog Ser 317:245-258

Wilson MT, Jump CM, Buchheister A (2009) Ecology of small neritic fishes in the western Gulf of Alaska. II. Consumption of krill in relation to standing stock and the physical environment. Mar Ecol Prog Ser 392:239-251

Wyllie-Echeverria T, Lenarz WH, Reilly CA (1990) Survey of the abundance and distribution of pelagic young-of-theyear rockfishes off central California. NOAA Tech Memo NMFS-SWFC-147, US Dept of Commerce, Southwest Fisheries Science Center, National Marine Fisheries Service, Tiburon, CA

Yang MS, Dodd K, Hibpshman R, Whitehouse A (2006) Food habits of groundfishes in the Gulf of Alaska in 1999 and 2001. NOAA Tech Memo NMFS-AFSC-164, US Dept of Commerce, Alaska Fisheries Science Center, National Marine Fisheries Service, Seattle, WA

Submitted: December 10, 2008; Accepted: June 12, 2009

Proofs received from author(s): October 5, 2009 